\title{
Ortaokul Beden Eğitimi ve Spor Dersi Öğretim Programının Temel İlkelerine İlişkin Beden Eğitimi Öğretmenlerinin Görüşleri (Sakarya İli Örneği)
}

\author{
Enes IŞIKGÖZ*
}

Öz

$\mathrm{Bu}$ araştırmanın amac1; Ortaokul 5-6-7-8. sınıflar beden eğitimi ve spor dersi öğretim programının temel ilkelerine ilişkin beden eğitimi öğretmenlerinin görüşlerini belirlemektir. Bu amaçla, öğretim programında yer alan on dokuz temel ilkeyi içeren veri toplama aracı oluşturulmuştur. Araştırma grubunu 2014-2015 eğitim öğretim yılında Sakarya ili merkez ilçeleri resmi ortaokullarında görev yapan 87 beden eğitimi öğretmeni oluşturmaktadır. Elde edilen veriler IBM SPSS 22.0 istatistik paket programı ile çözümlenmiş, verilerin analizinde tanımlayıcı istatistik testlerinin yanı sıra parametrik olmayan Kruskal Wallis-H ve Mann-Whitney U testleri kullanılmıştır. Araştırma sonucun$\mathrm{da}$, öğretmenlerin ortaokul beden eğitimi dersi öğretim programında belirlenen temel ilkelerine olumlu yaklaştıkları, öğretmenlerin görüşleri arasında sadece hizmet yılı ve eğitim durumu değişkenlerinde anlamlı farklılaşma olduğu görülmüştür.

Anahtar Kelimeler: Ortaokul, Beden Eğitimi ve Spor Dersi, Öğretim Programı, Program Değerlendirme.

\section{Opinions of The Physical Education Teachers About The}

\author{
Basic Principles of The Secondary School Physical \\ Education Lesson's Curriculum (The Sample of Sakarya \\ Province)
}

\begin{abstract}
The aim of this research; It is to define the thoughts of the physical education teachers about the basic principles of the 5th, 6th, 7th, 8th grades' physical education lesson. So a means of data collection including nineteen basic principles of the curriculum has been created. The team of the research consists of 87 physical education teachers working in the central Secondary Schools in Sakarya in the $2014-2015$. The data collected in the research has been analysed with the IBM SPSS Statistics 22.0 programme, apart from the descriptive statistics tests, Kruskal Wallis-H, Mann-Whitney U tests have been applied. As a result of the research, it has been understood that the teachers have a positive approach about the principles of the curriculum, but among the opinions of the teachers, there is a significant differentiation in their academic background and years of service.
\end{abstract}

*Yrd. Doç. Dr., pdgenes@gmail.com, Batman Üniversitesi Beden Eğitimi ve Spor Yüksekokulu 
Keywords: Secondary School, Physical Education Lesson, Curriculum, Analysing Curriculum.

\section{GíRİ̧̧}

Tarihsel süreç içerisinde ister formal ister informal olsun bireylerin toplumsal beklentiler doğrultusunda eğitilme düşüncesi eğitim ve öğretim olgusunu sürekli dinamik kılmıştır. Eğitim amaçla başlar, öğretme-öğrenme etkinlikleri devam edip değerlendirme süreci ile son bulmaktadır (Fidan ve Erden, 2000). Ülkelerin eğitim politikaları doğrultusunda şekillenen formal eğitim ile bireylerde oluşturulmak istenen kazanımlar ve hedef davranışlar bu amaçla hazırlanan ve geliştirilen öğretim programları ile sağlanmaktadır.

Günün koşulları, toplumsal ihtiyaç ve beklentiler beraberinde öğretim programlarında da değişmelere yol açmakta, küçük yaştan itibaren okullu olan çocukların yetiştirilmesinde öngörülen konu alanları ve bu konu alanlarına ilişkin planlamalar kapsamında yer alan öğretim programları da durağan olmayan bir şekilde planlanıp geliştirilir (Demirhan ve diğ., 2008; 157). Öğretim programlarının oluşturulmasında pek çok ülkede olduğu gibi ülkemizde de en yaygın olan yaklaşım programların derslerden meydana gelmesidir. Derslere göre düzenlenen programların önemli özelliklilerinden biri içeriğinin en iyi anlaşılabilecek biçimde düzenlenmesidir (Varış, 1996).

Milli Eğitim Temel Kanunu'nun, Türk Milli Eğitiminin amaçlarını düzenleyen ikinci maddesinde Türk milletinin bütün fertlerini; beden, zihin, ahlak, ruh ve duygu bakımlarmdan dengeli ve sağlıkl şekilde gelişmiş bir kişiliğe ve karaktere, hür ve bilimsel düşünme gücüne, geniş bir dünya görüşüne sahip, insan haklarına saygll, kişilik ve teşebbüse değger veren, topluma karşı sorumluluk duyan; yapıcl, yaratıcı ve verimli kişiler olarak yetiştirmek; olarak tanımlamıştır (Milli Eğitim Temel Kanunu, 1973, madde 2).
Toplumsal açıdan beklenen ve istenen davranışları kazanmış bireylerin yetiştirilmesinde kuşkusuz eğitim önemli bir yere sahiptir. Bireyleri fiziksel, zihinsel, duygusal ve toplumsal yönleriyle bir bütün olarak yetiştirmek çağdaş eğitimin temel ilkelerindendir (Yamaner, 2001). Millî Eğitim Temel Kanunu'nun ikinci maddesinde ifade edilen Türk Millî Eğitiminin amaçları esas alınarak Talim ve Terbiye Kurulu Başkanlığının 19.06.2013 tarih ve 56 sayılı karar1 ile 2013-2014 Öğretim Yılından itibaren uygulanmak üzere Ortaokul Beden Eğitimi ve Spor Dersi (5, 6, 7 ve 8. sinıflar) Öğretim Programı kabul edilmiştir. Bu programın amacı; Öğrencilerin yaşamları boyunca kullanacakları hareket, sağlıklı yaşam, öz yönetim, sosyal ve düşünme becerilerini geliştirerek bir sonraki eğitim düzeyine hazırlanmaları olarak belirlenmiştir.

Öğretim programında okul öncesinden başlayarak ortaöğretimin sonuna kadar olan süreçte, beden eğitimine ve spora katılımın, öğrencilerin fiziksel, duygusal, sosyal ve zihinsel özelliklerini geliştirmede önemli bir rolünün olduğu, bu süreçte beden eğitimi ve spor dersinden öncelikle beklenen, öğrencilere hareket yetkinliklerini geliştirmede, aktif ve sağlıklı yaşam alışkanlıkları edinmede yol gösterici ve destekleyici olması, öğrencilerin, beden eğitimi ve spor yolu ile özyönetim, sosyal ve düşünme becerilerini de geliştirebilmeleri olarak vurgulanmıştır. Çünkü zihinsel, duyuşsal ve sosyal yönlerden sağlıklı ve dengeli bir gelişim, beden eğitimi ve sporun başta gelen amaçlarındandır (Avşar, 2009: 82). Bu amaçların gerçekleşmesi sürecinde beden ve ruh yapısının eğitilerek geliştirilmesinde en etkili araç, hareket faktörünün her çeşidini ve ilkelerini kapsayan beden eğitimi ve spor eğitimidir (İnal, 2013: 37).

Beden eğitimi ve spor etkinlikleri, eğitimin bütünleyici bir parçası olup, bedensel, ruhsal, 
sosyal ve duygusal yönden becerileri gelişmiş sağlıklı insanların yetiştirilmesinde önemli bir araçtır (Doğar, 1994). Kuşkusuz bireylerin bedensel ve ruhsal yönden sağlıklı ve mutlu olması, toplumsal kalkınmanın da önde gelen koşullarındandır (Taşmektepligil ve diğ., 2006; 139). İkinci kademe olarak ortaokulu içeren ilköğretimin amaçlarından biri, bireylere yetenekleri doğrultusunda temel bilgi, beceri, tutum ve alışkanlıklar kazandırarak toplumla uyumlu, dengeli ve sağlıklı fertler yetiştirmektir.

Sporun toplumsal hayat içerisindeki işgal ettiği yer gün geçtikçe büyük boyutlara ulaşmaktadır. Çünkü spor, bir yandan modern yaşamın hazırladığı teknolojik kolaylıklar nedeniyle ortaya çıkan hareketsiz yaşama karşı bir alternatif ve sağlıklı kalabilmenin bir yolu olarak kullanılmaktadır (Alkurt, 2012). Beden eğitimi dersi tüm bu amaçları gerçekleştirmede önemli bir konuma sahiptir. Hızlı kentleşmenin birey üzerindeki olumsuz etkilerini azaltarak sağlıklı bir toplum için beden eğitimi ve spor etkinlikleri insan yaşamında vazgeçilmez hale getirilmelidir. Bunun sağlanabileceği en uygun yaş grubunu ilköğretim öğrencileri oluşturmaktadır (DPT, 2000). Aynı zamanda beden eğitimi, çocuk ve gençlerin farklı etkinliklerde bulunarak yaşamları boyunca fiziksel rahatlamasının da bir yolu olarak görülmüştür (Eurydice Raporu, 2013).

Fiziksel etkinliğin yaşam boyu sağlığa ilişkin yararlarını anlamak için çocukluk döneminde önemli fırsatların elde edilebileceği ve beden eğitimi derslerinin de bu konuda önemli bir araç olabileceği söylenebilir (Arslan ve Altay, 2008). Ortaokul beden eğitimi ve spor dersi öğretim programında istenilen amaçlara ulaşmak için uygulama alanı yaşamın kendisi olarak vurgulanmış, ders içi, okul içi ve okul dışı öğrenme ve uygulama fırsatlarının birbirleri ile ilişkilendirilmesinin önemine değinilmiştir.
Ortaokul beden eğitimi ve spor dersi öğretim programı bu eğitim öncelikleri doğrultusunda hazırlanmış, programının dayandığı on dokuz temel ilke şu şekilde sıralanmıştır;

1. Fiziksel etkinlikler, oyun ve spor yoluyla öğrenme temellidir.

2. Öğrencilerin bilişsel, duyuşsal ve psikomotor gelişimleri bir bütün olarak ele alınmıştır.

3. Öğrenci merkezli ortamlarda, öğrencilerin kendi öğrenmelerini yapılandırmalarına imkân verir.

4. Süreç ağırlıklıdır.

5. Gelişimsel ve sarmal bir yapıdadır.

6. Esnek bir yapıdadır.

7. Temalar/konular istenilen kazanımlara ulaşmada bir araçtır.

8. Öğrencilerin eğitiminde, çevresi ve diğger kişilerle deneyimleri önemlidir.

9. Öğrenme-öğretme ortamlarında bireysel, eşli ve grupla çalısmalar dengeli bir şekilde sunulur.

10. Uygulamalar strasinda öğrencilerin, kendilerini fiziksel ve duygusal olarak güvende hissetmeleri önemlidir.

11. Yaratıcılığı geliştirme, eleştirel ve yansitıcı düşünme ön plandadır.

12. Evrensel ve toplumsal değerlere yer verilmiştir.

13. Centilmence oyun ve mücadele anlayışı geliştirmek hedeflenir.

14. Öğretmene özgürlük tanır.

15. Tüm öğrencilerin katılımı önemlidir.

16. Çevreye ve doğaya duyarllık önemlidir.

17. Eğlenerek öğrenme ortamı sunar.

18. Değerlendirme süreci çok yönlüdür.

19. Aktif ve sağhlklı yaşam alışkanlığı kazandırır.

Öğretim programına adeta yön veren ve programın ana gayesi konumunda olan bu ilkelerin 
öğrenme ve öğretme sürecindeki durumunu, öğrencilere yansımasını ve başarısını belirleyici konumunda olan en önemli unsur dersin öğretmenleridir. 30.03.2012 tarihinde TBMM' de yasalaşan 6287 sayılı “İlköğretim ve Eğitim Kanunu ile Bazı Kanunlarda Değişiklik Yapılmasına Dair Kanun" ile eğitim sisteminde değişikliğe gidilerek okullar yeniden yapılandırılmış, kamuoyunda 4+4+4 olarak bilinen şekliyle okullar, 4 yıl ilkokul, 4 yıl ortaokul ve 4 yıl lise olmak üzere 12 yıl zorunlu eğitim biçiminde yeniden düzenlenmiştir. Bu düzenleme ile birlikte 1997 yılında başlayan kesintisiz ilköğretim (1-8. sınıf) uygulamasına son verilmiş, mevcut ilköğretim okulları ilkokul ve ortaokul olarak birbirinden ayrılmıştır. Sistemdeki bu değişikliğe paralel olarak mevcut ilköğretim okulu derslerinin öğretim programları da Talim ve Terbiye Kurulu Başkalığınca ilkokul ve ortaokul öğretim programları olarak yeniden düzenlenmeye başlanmış ve kademeli olarak uygulamaya sokulmuştur. Bu amaçla beden eğitimi ve spor dersi öğretim programında da zorunlu olarak değişikliğe gidilmiştir. MEB Talim Terbiye Kurulunun 28.08.2006 tarihli ve 349 sayılı kararı ile kabul edilen İlköğretim Beden Eğitimi (1-8. sınıflar) Dersi Öğretim Programının, 2013-2014 öğretim yılından itibaren ortaokul 5, 6, 7 ve 8 . sinıflar ile ilkokul 1 ve 2. sınıflardan başlamak üzere kademeli olarak uygulamadan kaldırılması, yerine MEB Temel Eğitim Genel Müdürlüğünün 12.04.2013 tarihli ve 43769797/101.01/589507 sayılı yazısı üzerine kurulda görüşülen Ortaokul Beden Eğitimi ve Spor Dersi (5, 6, 7 ve 8. sinıflar) Öğretim Programının, 2013-2014 öğretim yılından itibaren uygulanmak üzere kabul edilerek yürürlüğe girmesi kararlaştırılmıştır.

Öğretim programının daha iyiye doğru geliştirilmesi için eksik yönlerinin tamamlanıp yanlışlarının düzeltilmesi ve yeni gelişmelerle desteklenmesi gerekir (Erden, 1993). Çünkü Ortaokul dönemi, öğrencilerin ilkokul döneminde geliş- tirdikleri temel ve birleştirilmiş hareket becerilerini, çeşitli spor ve etkinlik gruplarına hazırlayıcı oyun ve etkinliklerle pekiştirerek, spora özgü yeteneklere altyapı oluşturdukları bir dönemdir (Darst ve diğ., 2012).

2013-2014 eğitim öğretim yılında yürürlüğe giren ortaokul (5-6-7-8. Sınıflar) beden eğitimi ve spor dersi öğretim programının ilköğretim okullarından sonra yeniden yapılandırılan ortaokullarda ilk kez uygulanmakta olması, dersin öğretmenlerince yeni programın temel ilkelerine ilişkin görüşlerinin ilk kez alınması ve henüz iki yıllık olan programın temel ilkelerine dönük ilk araştırma olması araştırmayı önemli kılmaktadır. Araştırma iki yıllık süreçte uygulanan öğretim programının temel ilkelerine ilişkin var olan durumu öğretmenlerin görüşleri doğrultusunda ortaya koymayı amaçlamaktadır. Araştırmada aşağıda ki sorulara yanıt aranmıştır;

1- Ortaokul (5-6-7-8. sinıflar) öğretim programinda belirlenen temel ilkelere ilişkin olarak beden eğitimi öğretmenlerinin görüşleri nelerdir?

2- Ortaokul (5-6-7-8. sinıflar) öğretim programında belirlenen temel ilkelere ilişkin olarak beden eğitimi öğretmenlerinin görüşleri arasında; Cinsiyet, hizmet yılı ve eğitim durumu değişkenleri açısından herhangi bir farklılaşma var midir?

\section{YÖNTEM}

$\mathrm{Bu}$ araştırmada tarama modeli kullanılmıştır. Araştırmada ortaokullarda halen görev yapan beden eğitimi öğretmenlerinin ortaokul (5-6-78. sınıflar) öğretim programının temel ilkelerine ilişkin görüşleri belirlenmeye çalışıldığı için betimsel bir araştırmadır. Araştırma grubunu 2014-2015 eğitim öğretim yılı ikinci döneminde Sakarya ili merkez ilçeleri resmi ortaokul ve imam hatip ortaokullarında görev yapan 34'ü bayan 85'i erkek olmak üzere toplam 119 beden 
eğitimi öğretmeni oluşturmaktadır. Araştırma grubuna dâhil okul ve öğretmen sayıları Milli Eğitim Müdürlüğünün ilgili biriminden alınmiştır.

Araştırmacı tarafından, “MEB Ortaokul (5-6-78. sınıflar) Beden Eğitimi ve Spor Dersi Öğretim Programı"nda yer alan ilkeler, veri toplama formuna dönüştürülerek anket edilmiş ve uygulanmıştır. Anket iki bölümden oluşmakta, birinci bölümde katılımcıların demografik özelliklerine ilişkin 3 soru, ikinci bölümdeki ise ortaokul beden eğitimi ve spor dersi öğretim programının temel ilkelerine ilişkin 19 soru yer almaktadır. İkinci bölüm sorularının cevaplama seçenekleri beşli Likert tipine göre; “1- Kesinlikle Katılmıyorum, 2- Katılmiyorum, 3- Kararsızım, 4- Katılıyorum, 5- Tamamen Katılıyorum" seçeneklerinden oluşmaktadır. Anket; Google drive servisinin google dokümanlar yöntemi kullanılarak elektronik ortama aktarılmış, yalnızca tek girişe izin verilecek şekilde okulların ve öğretmenlerin e-posta adreslerine gönderilmiş, elektronik ortamda ulaşılamayan öğretmenlere ise bizzat araştırmacı tarafından okullarına gidilerek anketlerin doldurulması sağlanmıştır. Anketleri; 63'ü erkek, 24'ü bayan öğretmen olmak üzere toplam 87 öğretmen cevaplamıştır. İncelenen anketlerin tümü veri açısından sağlıklı görülerek analize dâhil edilmiştir.

Verilerin analizinde IBM SPSS 22.0 istatistik paket program uygulanmış, demografik bilgiler ile öğretmenlerin görüşlerinin belirlenmesi için betimsel istatistik kısmında frekans, yüzde ve aritmetik ortalamalara yer verilmiştir. Verilerin normal dağılım gösterip göstermediğine ilişkin Kolmogorov-Smirnov Testi yapılmıştır. Normal dağılıma sahip olmayan verilerin analizi için nonparametrik testlerden Kruskal Wallis-H ve Mann-Whitney $U$ testleri kullanılmıştır. Ankete öğretmenlerin vermiş olduğu cevaplar doğrultusunda Cronbach Alpha güvenilirlik katsayısı 0.84 olarak bulunmuştur. Bu sonuca göre anketin oldukça güvenilir olduğu söylenebilir.

\section{BULGULAR}

Bu bölümde, ortaokul ve imam hatip ortaokullarında görev yapan beden eğitimi öğretmenlerinin ankette yer alan sorulara vermiş oldukları cevaplardan elde edilen bulgulara yer verilmiştir.

Tablo 1. Araştırmaya Katılan Beden Eğitimi Öğretmenlerinin Cinsiyet, Hizmet Süresi ve Eğitimi Durumu Değişkenlerine Göre Dağılımları

\begin{tabular}{lcc}
\hline Cinsiyet & $n$ & $\%$ \\
\hline Bayan & 24 & 27,6 \\
Erkek & 63 & 72.4 \\
\hline Hizmet Süresi & $\mathrm{n}$ & $\%$ \\
\hline $1-5$ Yil & 12 & 13.8 \\
$6-10$ Yıl & 24 & 27.6 \\
$11-15$ Yıl & 35 & 40.2 \\
$16-20$ Yil & 12 & 13.8 \\
21 Yıl ve üstü & 4 & 4.6 \\
\hline Eğitim Durumu & $\mathrm{n}$ & $\%$ \\
\hline Lisans & 73 & 83.9 \\
Yükseklisans & 14 & 16.1 \\
\hline Toplam & 87 & 100 \\
\hline
\end{tabular}


Tablo 1' e göre; Araştırmaya katılan toplam 87 Beden Eğitimi Öğretmeninin 24' ü (\% 27.6) bayan, 63' ü (\% 72.4) erkektir. Öğretmenlerin $12^{\prime}$ si (\% 13.8) 1-5 hizmet yılına, 24' ü (\%27.6) 610 hizmet yllına, 35' i (\% 40.2) 11-15 hizmet yılına, 12' si (\% 13.8) 16-20 hizmet yilına, 4 öğretmen ise (\% 4.6) 21 yıl ve üstü hizmet yıll-

Tablo 2. Beden Eğitimi ve Spor Dersi Öğretim Programının Temel İlkelerine İlişkin Beden Eğitimi Öğretmenlerinin Görüşleri na sahip oldukları belirlenmiştir. Öğretmenlerin en çok 6-15 yıl arasında (\% 67.8) kümelendikleri görülmüştür. Araştırmaya katılan beden eğitimi öğretmenlerinin 73’ ü (\% 83.9) lisans, 14' ü (\%16.1) yükseklisans öğrenim düzeyinde oldukları belirlenmiştir.

\begin{tabular}{|c|c|c|c|c|c|c|c|}
\hline \multicolumn{2}{|l|}{ İlkeler } & 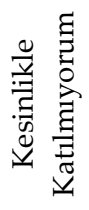 & 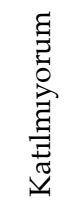 & 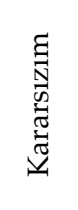 & 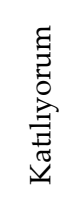 & 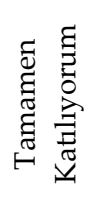 & $\bar{X}$ \\
\hline \multirow{2}{*}{$\begin{array}{l}\text { 1. Fiziksel etkinlikler, oyun ve spor yoluyla öğren- } \\
\text { me temellidir. }\end{array}$} & $\mathrm{n}$ & 3 & 10 & 3 & 31 & 40 & \multirow{2}{*}{4.09} \\
\hline & $\%$ & 3.4 & 11.5 & 3.4 & 35.6 & 46 & \\
\hline 2. Öğrencilerin bilişsel, duyuşsal ve psikomotor & $\mathrm{n}$ & 4 & 5 & 1 & 32 & 45 & \multirow{2}{*}{4.25} \\
\hline gelişimleri bir bütün olarak ele alınmıştır. & $\%$ & 4.6 & 5.7 & 1,1 & 36.8 & 51.7 & \\
\hline 3. Öğrenci merkezli ortamlarda, öğrencilerin kendi & $\mathrm{n}$ & 5 & 11 & 6 & 33 & 32 & \multirow{2}{*}{3.87} \\
\hline öğrenmelerini yapılandırmalarına imkân verir. & $\%$ & 5.7 & 12.6 & 6.9 & 37.9 & 36.8 & \\
\hline \multirow{2}{*}{ 4. Süreç ağırlıklıdır. } & $\mathrm{n}$ & 7 & 13 & 7 & 39 & 21 & \multirow{2}{*}{3.62} \\
\hline & $\%$ & 8 & 14.9 & 8 & 44.8 & 24.1 & \\
\hline \multirow{2}{*}{ 5. Gelişimsel ve sarmal bir yapıdadır. } & $\mathrm{n}$ & 7 & 17 & 4 & 45 & 14 & \multirow{2}{*}{3.48} \\
\hline & $\%$ & 8 & 19.5 & 4.6 & 51.7 & 16.1 & \\
\hline \multirow{2}{*}{ 6. Esnek bir yapıdadır. } & $\mathrm{n}$ & 3 & 3 & 5 & 61 & 15 & \multirow{2}{*}{3.94} \\
\hline & $\%$ & 3.4 & 3.4 & 5.7 & 70.1 & 17.2 & \\
\hline \multirow{2}{*}{$\begin{array}{l}\text { 7. Temalar/konular istenilen kazanımlara ulaşmada } \\
\text { bir araçtır. }\end{array}$} & $\mathrm{n}$ & 1 & 5 & 9 & 36 & 36 & \multirow{2}{*}{4.16} \\
\hline & $\%$ & 1.1 & 5,7 & 10.3 & 41.4 & 41.4 & \\
\hline \multirow{2}{*}{$\begin{array}{l}\text { 8. Öğrencilerin eğitiminde, çevresi ve diğer kişilerle } \\
\text { deneyimleri önemlidir. }\end{array}$} & $\mathrm{n}$ & 1 & 4 & 1 & 32 & 49 & \multirow{2}{*}{4.43} \\
\hline & $\%$ & 1.1 & 4.6 & 1.1 & 36.8 & 56.3 & \\
\hline \multirow{2}{*}{$\begin{array}{l}\text { 9.Öğrenme-öğretme ortamlarında bireysel, eşli ve } \\
\text { grupla çalışmalar dengeli bir şekilde sunulur }\end{array}$} & $\mathrm{n}$ & 3 & 7 & 6 & 54 & 17 & \multirow{2}{*}{3.86} \\
\hline & $\%$ & 3.4 & 8 & 6.9 & 62.1 & 19.5 & \\
\hline \multirow{2}{*}{$\begin{array}{l}\text { 10. Uygulamalar sırasında öğrencilerin, kendilerini } \\
\text { fiziksel ve duygusal olarak güvende hissetmeleri } \\
\text { önemlidir. }\end{array}$} & $\mathrm{n}$ & 2 & 2 & 2 & 47 & 34 & \multirow[b]{2}{*}{4.25} \\
\hline & $\%$ & 2.3 & 2.3 & 2.3 & 54 & 39.1 & \\
\hline \multirow{2}{*}{$\begin{array}{l}\text { 11. Yaratıcılığı geliştirme, eleştirel ve yansıtıcı } \\
\text { düşünme ön plandadır. }\end{array}$} & $\mathrm{n}$ & 5 & 16 & 8 & 43 & 15 & \multirow{2}{*}{3.54} \\
\hline & $\%$ & 5.7 & 18.4 & 9.2 & 49.4 & 17.2 & \\
\hline \multirow{2}{*}{ 12. Evrensel ve toplumsal değerlere yer verilmiştir. } & $\mathrm{n}$ & 3 & 18 & 7 & 41 & 18 & \multirow{2}{*}{3.61} \\
\hline & $\%$ & 3.4 & 20.7 & 8 & 47.1 & 20.7 & \\
\hline \multirow{2}{*}{$\begin{array}{l}\text { 13. Centilmence oyun ve mücadele anlayışı } \\
\text { geliştirmek hedeflenir. }\end{array}$} & $\mathrm{n}$ & 5 & 9 & 2 & 56 & 15 & \multirow{2}{*}{3.77} \\
\hline & $\%$ & 5.7 & 10.3 & 2.3 & 64.4 & 17.2 & \\
\hline \multirow{2}{*}{ 14. Öğretmene özgürlük tanır. } & $\mathrm{n}$ & 1 & 11 & 3 & 57 & 15 & 385 \\
\hline & $\%$ & 1.1 & 12.6 & 3.4 & 65.5 & 17.2 & 0.00 \\
\hline & $\mathrm{n}$ & 4 & 10 & 6 & 43 & 24 & \\
\hline 15. Ium ogrencilerın katılımı onemiıdir. & $\%$ & 4.6 & 11.5 & 6.9 & 49.4 & 27.6 & 3.84 \\
\hline 16. Cevreve ve doğava duvarlılık önemlidir. & $\mathrm{n}$ & 7 & 18 & 4 & 43 & 15 & 347 \\
\hline 10. Çevreye ve aogaya auyarmmk onemmär. & $\%$ & 8 & 20.7 & 4.6 & 49.4 & 17.2 & $0.4 /$ \\
\hline 17 Fŏlenerek öŏrenme ortamı sunar & $\mathrm{n}$ & 12 & 30 & 3 & 32 & 10 & 298 \\
\hline 1\%. Egrenerek ogrenme ortamm sunar. & $\%$ & 13.8 & 34.5 & 3.4 & 36.8 & 11.5 & 2.90 \\
\hline 18 Değerlendirme süreci cok vönlüdür & $\mathrm{n}$ & 7 & 15 & 5 & 32 & 28 & 368 \\
\hline 18. Degerlenairme surecı çok yoniuaur. & $\%$ & 8 & 17.2 & 5.7 & 36.8 & 32.2 & 3.68 \\
\hline
\end{tabular}

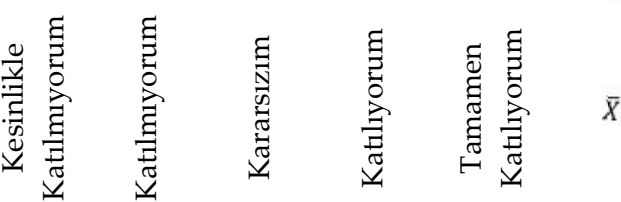

1. Fiziksel etkinlikler, oyun ve spor yoluyla öğrenme temellidir.

. Ögrencilerin bilişsel, duyuşsal ve psikomotor gelişimleri bir bütün olarak ele alınmıştır.

Ogrenci merkezli ortamlarda, örencilerin kendi

4. Süreç ağırlıklıdır.

5. Gelişimsel ve sarmal bir yapıdadır.

Esnek bir yapıdadir.

emalar/konular istenilen kazanımlara ulaşmada

8. Öğrencilerin eğitiminde, çevresi ve diğer kişilerle deneyimleri önemlidir. 10. Uygulamalar sırasında öğrencilerin, kendilerini ziksel ve duygusal olarak güvende hissetmeler

11. Yaratıcılığı geliştirme, eleştirel ve yansıtıcı

13. Centilmence oyun ve mücadele anlayışı geliştirmek hedeflenir.

15. Tüm öğrencilerin katılımı önemlidir. 


\begin{tabular}{cccccccc}
\hline 19. Aktif ve sağlıklı yaşam alışkanlığı kazandırır. & $\mathrm{n}$ & 3 & 8 & 3 & 39 & 34 & 4.07 \\
& $\%$ & 3.4 & 9.2 & 3.4 & 44.8 & 39.1 & \\
& & 4.98 & 12.81 & 5.12 & 48.15 & 28.85 & 3.83 \\
\hline
\end{tabular}

Tablo 2' ye göre beden eğitimi öğretmenleri ortaokul beden eğitimi ve spor dersi öğretim programındaki temel ilkelerinden birincisi olan fiziksel etkinlikler, oyun ve spor yoluyla öğrenme temellidir ilkesine büyük çoğunluğunun ( \% 81.6) katıldıkları, \% 14.9' unun katılmadıkları görülmüştür. Öğrencilerin bilişsel, duyuşsal ve psikomotor gelişimleri bir bütün olarak ele alınmıştır ilkesine ise öğretmenlerin \% 88.5' inin büyük bir çoğunlukla katıldıkları, \% 10.3' ünün bu ilkeye katılmadıkları, öğrenci merkezli ortamlarda, öğrencilerin kendi öğrenmelerini yapılandırmalarına imkân verir ilkesine \% 74.7 oranında katıldıkları, \% 18.3 oranında ise katılmadıkları belirlenmiştir.

Program süreç ağırlıklıdır ilkesine öğretmenlerin \% 68.9' unun katıldıkları, \% 22.9' unun katılmadıkları, \% 8'inin ise kararsız kaldıkları, program gelişimsel ve sarmal bir yapıdadır ilkesine öğretmenlerin \% 67.8' i katılmakta iken, \% 27.5' inin ise katılmadıkları belirlenmiştir. Her iki ilkeye katılmama oranının diğer ilkelere göre yüksek olduğu görülmüştür. Programın esnek bir yapıda olduğu ilkesine öğretmenlerin \% 87.3' ünün katıldıkları, \% 6.8 oranında katılmadıkları, temalar/konular istenilen kazanımlara ulaşmada bir araçtır ilkesine \% 82.8' inin katıldıkları, yine \% 6.8' inin katılmadıkları görülmüştür.

Öğrencilerin eğitiminde, çevresi ve diğer kişilerle deneyimleri önemlidir ilkesine öğretmenlerin \% 56.3' ü tamamen katılırken, \% 36.8' i ise katıldıklarını, programın ilkeleri içerisinde öğretmenlerin tamamına yakınının (\% 93.1) bu ilkeye katıldıkları belirlenmiştir. Öğrenmeöğretme ortamlarında bireysel, eşli ve grupla çalışmalar dengeli bir şekilde sunulur ilkesine öğretmenlerin \% 81.6' sının katıldıkları, \% 11.4' ünün katılmadıkları, uygulamalar sırasında öğrencilerin, kendilerini fiziksel ve duygusal olarak güvende hissetmeleri önemlidir ilkesine ise \% 93.1 oranında katıldıkları, \% 4.6 oranında katılmadıkları görülmüştür. Yine öğretmenlerin tamamına yakını öğrencilerin eğitiminde, çevresi ve diğer kişilerle deneyimleri önemlidir ilkesinde olduğu gibi uygulamalar sırasında öğrencilerin, kendilerini fiziksel ve duygusal olarak güvende hissetmeleri önemlidir ilkesine katıldıkları saptanmıştır.

Yine tablo 2' ye göre öğretmenlerin \% 66.6's1 öğretim programda yaratıcılı̆̆ı geliştirme, eleştirel ve yansıtıcı düşünme ön plandadır ilkesine katıldıklarını, \% 24.1' i katılmadıkları, programda evrensel ve toplumsal değerlere yer verilmiştir ilkesine ise \% 67.8' i katıldıklarını, yine \% 24.1' inin katılmadıkları görülmüştür. Centilmence oyun ve mücadele anlayışı geliştirmek hedeflenir ilkesine öğretmenlerin \% 81.6 oranında katıldıkları, \% 16 oranında katılmadıkları, programın öğretmene özgürlük tanıdığına ise \% 82.7' sinin katıldıkları, \% 13.7' sinin katılmadıkları her iki ilkeye de programın diğer ilkelerinde olduğu öğretmenlerin büyük çoğunlukla katıldıkları saptanmıştır.

Tüm öğrencilerin katılımı önemlidir ilkesine öğretmenlerin \% 77'sinin katıldıkları, \% 16.1' inin katılmadıkları, çevreye ve doğaya duyarlılık önemlidir ilkesine öğretmenlerin \% 66.6” s1 katılmakta iken, \% 28.7' sinin katılmadıkları, bu ilkeye olumsuz yaklaştıkları görülmüştür. Programin ilkelerinden; eğlenerek öğrenme ortamı sunar görüşüne öğretmenlerin \% 48.3' ü katıldığını beyan ederken, aynı oranda (\% 48.3) katılmadıklarını beyan etmişleridir. Toplam 19 ilkeyi içeren öğretim programında öğretmenlerin hemen hemen yarısı bu ilkeye olumsuz yaklaşmışlardır. Beden eğitimi ve spor derslerinin eğlenerek öğrenme ortamı sunması için ortaokul seviyesinde okullarda gerekli fiziksel alt yapı, araç gereç, tesis vb. eksikliklerin olma- 
s1 öğretmenlerin bu görüşe yönelmelerinde etkili olduğu düşünülmektedir.

Yine programın diğer ilkelerinden; değerlendirme süreci çok yönlüdür ilkesine öğretmenlerin \% 69' unun katıldıkları, \% 25.2' isinin katılmadıkları, aktif ve sağlıklı yaşam alışkanlığı kazandırır ilkesine ise büyük çoğunlukla (\% 83.9) katıldıkları, \%12.6'sının katılmadıkları görülmüştür. Programın temel ilkelerine ilişkin öğretmenlerin görüşlerinin ortalamasına bakıldığında; en yüksek ortalamanın sırasıyla; öğrencilerin eğitiminde, çevresi ve diğer kişilerle deneyimleri önemlidir ( $\bar{X}=4.43$ ), Öğrencilerin bilişsel, duyuşsal ve psikomotor gelişimleri bir bütün olarak ele alınmıştır $(\bar{X}=4.25)$, uygulamalar sırasında öğrencilerin, kendilerini fiziksel ve duygusal olarak güvende hissetmeleri önemlidir $(\bar{X}=4.25)$ ilkelerinde gerçekleştiği, öğretmenlerin bu ilkelere daha olumlu yaklaştıkları belirlenmiştir. Düşük ortalamanın ise; eğlenerek öğrenme ortamı sunar $(\bar{X}=2.98)$, çevreye ve doğaya duyarlılık önemlidir ( $\bar{X} 3.47)$, gelişimsel ve sarmal bir yapıdadır $(\bar{X}=3.54)$ ilkelerinde meydana geldiği, bu ilkelere öğretmenlerin daha az katıldıkları görülmüştür.

Tablo 3. Beden Eğitimi ve Spor Dersi Öğretim Programının Temel İlkeleri Ölçeğinden Elde Edilen Verilerin Normal Dağılım Gösterip Göstermediğini Belirlemek Amacıyla Yapılan Tek Örneklem Kolmogorov-Smirnov Testi Sonuçları

\begin{tabular}{lll}
\hline Değerler & Puan & \\
\hline$n$ & 87 & 77.8276 \\
Parametreler & $x$ & 5.87507 \\
K-Smirnov Z & ss & \\
$p$ & 2.093 & \\
\hline
\end{tabular}

Tabloda da görüldüğ̈ü üzere, beden eğitimi ve spor dersi öğretim programının temel ilkeleri ölçeğinden elde edilen puanların normal dağ1lım gösterip göstermediğini belirlemek amacıyla yapılan tek örneklem Kolmogorov-Smirnov testi sonucunda dağılımın normal dağılımdan farklılı̆̆1 anlamlı bulunduğundan $\quad(z=2.093$; $p<0.05)$ öğretmen görüşlerinin demografik değişkenlere göre karşılaştırılmasında nonparametrik testler kullanılmıştır.

Tablo 4. Öğretmenlerin Cinsiyet Değişkenine Göre Beden Eğitimi ve Spor Dersi Öğretim Programının

Temel İlkelerine İlişkin Görüşleri Arasındaki Farkın Anlamlılığını Test Etmek İçin Yapılan Non-

Parametrik Mann Whitney-U Testi Sonuçları

\begin{tabular}{lcccccc}
\hline Cinsiyet & $n$ & S.T. & S.O. & $U$ & $z$ & $p$ \\
\hline Bayan & 24 & 43.29 & 1039,00 & 739.000 & -0.163 & 0.871 \\
Erkek & 63 & 44.27 & 2789,00 & & \\
Toplam & 87 & & & & \\
\hline
\end{tabular}

Tablo 4' e göre, öğretmenlerin beden eğitimi ve spor dersi öğretim programının temel ilkeleri ölçeğinden almış oldukları puanların, cinsiyet değişkenine göre anlamlı bir şekilde farklılaşıp farklılaşmadığını belirlemek üzere yapılan nonparametrik Mann Whitney-U testi sonucunda, gruplar arasında anlamlı bir farklılık saptanmamıştır $(p=0.871>0.05)$. 
Tablo 5. Beden Eğitimi ve Spor Dersi Öğretim Programının Temel İlkelerine İlişkin Öğretmenlerin Hizmet Yılına Göre Görüşlerinin Farklılaşıp Farklılaşmadığını Belirlemek Üzere Yapılan Kruskal Wallis-H Testi Sonuçları

\begin{tabular}{cccccc}
\hline Hizmet y1l & $n$ & S.O. & S.D. & $X^{2}$ & $p$ \\
\hline $1-5$ yıl & 12 & 48.75 & & & \\
$6-10$ yıl & 24 & 35.58 & & & \\
$11-15$ yıl & 35 & 50.66 & 4 & 12.415 & $0.015^{*}$ \\
$16-20$ yıl & 12 & 29.63 & & & \\
21 y1l üstü & 4 & 65.13 & & & \\
Toplam & 87 & & & & \\
\hline
\end{tabular}

Tablo 5' e göre, beden eğitimi ve spor dersi öğretim programının temel ilkelerine ilişkin öğretmenlerin hizmet yılı değişkenine göre görüşlerinin farklılaşıp farklılaşmadığını belirlemek üzere yapılan Kruskal Wallis-H testi sonucunda fark istatistiksel olarak anlaml bulunmuştur ( $\mathrm{X}^{2}=12.415$; $\left.\mathrm{sd}=4, \mathrm{p}=0.015<0.05\right)$. Kruskal Wallis-H sonrası belirlenen anlamlı farklılığın hangi gruplardan kaynaklandığını belirlemek üzere tamamlayıcı karşılaştırma tekniklerine geçilmiştir. Bu amaçla kullanılan özel bir test tekniği bulunmadığından ikili karşılaştırmalarda tercih edilen Mann WhitneyU testi uygulanmıştır.

Analizlerin sonucunda farklılığın hizmet yılı 15 yıl olan grupla 16-20 yıl olan grup arasinda

Tablo 6. Beden Eğitimi ve Spor Dersi Öğretim Programının Temel İlkelerine İlişkin Öğretmenlerin Eğitim Durumuna Göre Görüşlerinin Farklılaşıp Farklılaşmadığını Belirlemek Üzere Yapılan Mann Whitney-U Testi Sonuçları

\begin{tabular}{ccccccc}
\hline Eğitim Durumu & $n$ & S.T. & S.O. & U & $z$ & $p$ \\
\hline Lisans & 73 & 46.84 & 3419.00 & & & \\
Yükseklisans & 14 & 29.21 & 409.00 & & & \\
Toplam & 87 & & & & & \\
\hline
\end{tabular}

Tablo 6' ya göre, öğretmenlerin beden eğitimi ve spor dersi öğretim programının temel ilkelerine ilişkin görüşlerinin eğitim durumlarına hizmet yıl1 1-5 y1l arasında olan grup lehine $(\mathrm{U}=23.500 ; \mathrm{z}=-2.864 ; \mathrm{p}=0.004 ; \mathrm{p}<0.05)$, hizmet yılı 6-10 yil olan grupla 11-15 yıl arasinda hizmet yılı 11-15 yıl olan grup lehine (U=280.000; $z=-$ 2.199; $\mathrm{p}=0.028 ; \mathrm{p}<0.05)$, hizmet yılı 6-10 yıl olan grupla 21 yıl ve üstü grup arasında hizmet yılı 21 yıl ve üstü olan grup lehine $(U=17,500 ; z=-$ 2.072; $\mathrm{p}=0.038 ; \mathrm{p}<0.05)$, hizmet y1l $11-15$ y1l olan grupla 16-20 y1l olan grup arasında 11-15 y1l olan grup lehine ( $\mathrm{U}=109.500 ; \mathrm{z}=-2.483$; $\mathrm{p}=0.013 ; \mathrm{P}<0.05)$, hizmet yılı 16-20 yıl olan grupla 21 yıl ve üstü grup arasında hizmet yılı 21 yıl ve üstü olan grup lehine $(U=7.000 ; z=-$ 2.086; $p=0.037 ; p<0.05)$ gerçekleştiği belirlenmiştir.

göre anlamlı bir şekilde farklılaşıp farklılaşmadığını belirlemek üzere yapılan non-parametrik Mann Whitney-U testi sonucunda, gruplar 
arasında anlamlı bir farklılık saptanmıştır $(p=0,01<0,05)$. Sıra ortalamalarına bakıldığında lisans mezunu olan öğretmen grubunun beden eğitimi ve spor dersinin temel ilkelerine yönelik, yükseklisans öğrenim düzeyindeki öğretmen grubuna göre daha olumlu bir tutum içerisinde oldukları görülmüştür.

\section{TARTIŞMA VE SONUÇ}

Beden eğitimi öğretmenlerinin 2013-2014 eğitim öğretim yılında uygulamaya konulan beden eğitimi ve spor dersi öğretim programının iki yıllık uygulama sonucunda programin dayandığı temel ilkelerine ilişkin genel görüşlerinin olumlu olduğu görülmektedir. Literatürde Havadar ve Taşdan (2015) tarafından yapılan beden eğitimi öğretmenlerinin ilköğretim 4.-5. sınıf öğretim programları hakkında ki görüşlerine bakıldığında, öğretmenlerin programa ilişkin olumlu bakış açsısı içerisinde oldukları görülmüştür.

Ortaokul beden eğitimi ve spor dersi için belirlenen toplam 19 ilkenin ortalamasına bakıld1ğında, öğretmenlerin \% 48.15'inin bu ilkelere katıldıkları \% 28.85'inin ise tamamen katıldıkları, toplam katılım oranının \% 77 olduğu, olumsuz görüş bildiren öğretmenlerin oranının \% 17.79 olduğu sonucuna varılmıştır. Okulların yeniden yapılandırılması, eski sistemde ilkokul kademesine dâhil olan 5. sinıfların ortaokula dâhil edilmesi ile beraber bir dizi yeniliklere rağmen öğretmenlerin görüşlerinin olumlu olması belirlenen temel ilkelerin programa yön verebilir nitelikte olduğunu düşündürmektedir.

Öğrencilerin eğitiminde, çevresi ve diğer kişilerle deneyimleri önemlidir ilkesine öğretmenlerin hemen hemen tamamına yakınının (\% 93.1) katıldıkları belirlenmiştir. Eğitim-öğretim sürecinde bireylerin çevresindeki deneyim ve yaşantıları önemlidir. Bireyler yaşamlarının ilk aylarından itibaren en basit davranış şekillerini bile taklit yoluyla geliştirir. Aile içerisindeki fertlerle başlayan bu taklit etmeler, giderek sevdiği, beğendiği ve hayranlık duyduğu, diğer büyüklerle devam eder. Sporcular, müzisyenler ve sinema oyuncuları gençlerin taklit etmeye en çok eğilim gösterdikleri kişilerdir. Bu yüzden sporcular örnek davranış ve alışkanlıklarıyla sosyalleşme sürecinde diğer kişilere iyi birer model olabilirler (Yücel, 2004). Nitekim bu ilke programın birinci sırasında yer alan, fiziksel etkinlikler, oyun ve spor yoluyla öğrenme temellidir ilkesinin de tamamlayıcısı konumundadır. Beden eğitimi derslerinde düzenli fiziksel aktivite yapma alışkanlığının geliştirilebilmesi için öncelikli olarak öğrencilerin yaşam boyu sürdürebilecekleri, fiziksel becerileri öğrenebilecekleri ve neşe içinde etkinliklere katılabilecekleri bir eğitim ortamı önerilmektedir (Yıldırım ve diğg., 2007).

Yine temalar/konular istenilen kazanımlara ulaşmada bir araçtır ilkesine öğretmenlerin büyük çoğunluğunun olumlu yaklaşması, 2005 yılından itibaren öğretim programlarında uygulanmakta olan yapılandırmacı eğitim anlayışının olumlu yansıması olarak düşünülmektedir. Yapılan araştırmalar incelendiğinde yapılandırmacı eğitim anlayışına ilişkin öğretmenlerin olumlu yaklaştıkları görülmüştür. Güllü ve diğ. (2009) tarafından yürütülen “ilköğretimde Çalışan Beden Eğitimi Öğretmenlerinin Yapılandırmacı Yaklaşıma ve Beden Eğitimi Dersi Yeni Öğretim Programına İlişkin Görüşlerinin İncelenmesi" konulu çalışmada beden eğitimi öğretmenlerinin yapılandırmacı yaklaşıma ilişkin genel görüşlerinin olumlu olduğu görülmektedir. Beden eğitimi öğretmenleri yapılandırmacı eğitim yaklaşımının öğrenci merkezli olduğu, öğrencilerin sosyal gelişimlerini hızlandıran, onları düşünmeye ve araştırmaya sevk eden bir yaklaşım olduğu görüşüne olumlu yaklaşmışlardır. Bir başka araştırma sonucunda Bilir (2008), yeni beden eğitimi öğretim programının yapılandırmacı eğitim 
yaklaşımına uygun hazırlandığı tepsi edilmiştir.

Öğretmenlerin tüm ilkeler bazında ortalama olarak genel olumlu görüşlerine rağmen, öğretim programının eğlenerek öğrenme ortamı sunduğu ilkesine yaklaşık yarısının katılmaması (\% 48.3) dikkat çekicidir. Bu sonuç; Dalkıran ve ark. (2004) tarafından yapılan araştırmada ortaya çıkan "Beden eğitimi etkinliklerinin amaca uygun yapılamasında tesis ve araçgerecin önemli yeri vardır" görüşü ile benzer niteliktedir. Gülüm ve Bilir (2011) tarafından yapılan “Beden Eğitimi Öğretim Programının Uygulanabilme Koşulları İle İlgili Beden Eğitimi Öğretmenlerinin Görüşleri” konulu çalışmada da, öğretmenlerin okulların program için gerekli fiziksel koşullara (araç-gereç, tesis) sahip olmadığı yönünde benzer görüş bildirdikleri görülmüştür.

Güllü ve ark. (2007) yaptıkları "Beden Eğitimi Öğretmenlerinin 4., 5. ve 6. sınıf Beden Eğitimi Dersi Yeni Öğretim Programı Uygulamalarının İncelenmesi" konulu çalışmada beden eğitimi öğretmenlerinin yeni programın uygulanmasinda okulun alt yapi ve tesislerinin yetersiz geldiğini tespit etmişleridir. Okulların ayrıştırılması sonucu binaların fiziki şartlarının değişmesi, sportif tesis, araç ve gereçlere yönelik sağlıklı planlamanın yapılamaması, zaten eğitim kurumlarının genel anlamda zayıf yönlerinden biri olan sportif tesislerin eksikliği öğretmenleri bu görüşe sevk ettiği düşünülmektedir. Nitekim bu durumla ilgili olarak, MEB' in 2012 yılı okul bahçeleri düzenleme ilkeleri, ihtiyaç programları açıklamaları ve örnek projelerde, okul bahçelerinde, yeterli büyüklükte tören alanı, gezinti yolları, yeşil alan bırakılma$l 1$, tel örgülerle çevrili açık spor tesisleri (voleybol, basketbol, mini futbol sahası) ile geleneksel çocuk oyunlarına uygun alanlar ayrılmalıdır hususlarına yer verilmiştir (MEB, 2012: 2). Okul Spor Faaliyetleri Yönetmeliğinin; Saha ve tesis- lerin kullanımı 26. maddesinde "Millî Eğitim Bakanlığı ile Genel Müdürlüğe ait tesislerin etkin ve verimli kullanılabilmesi için il müdürlükleri ile il milli eğitim müdürlükleri tarafından gerekli tedbirler alınır, yarışma ve organizasyonlarda herhangi bir aksaklığa meydan verilmemesi sağlanır" hükümlerine yer verilerek tesis eksikliği olan okullara yönelik düzenleme yapılmıştır.

Öğretim programı süreç ağırlıklıdır, gelişimsel ve sarmal bir yapıdadır ilkelerine de öğretmenlerin yaklaşık \% 30 oranında katılmadıkları görülmüştür. Program 2013-2014 öğretim y1lında uygulamaya konulduğundan programla başlangıç yapan beşinci sınıf öğrencilerinin 4 yıllık uygulama sonuçlarının henüz görülmemiş olması öğretmenleri bu görüşe sevk ettiği düşünülmektedir. Yine Gülüm ve Bilir (2011) tarafından yapılan çalışmada, programın öngördüğü öğrenme etkinlikleri ile öğretmenlerin olumsuz görüş içersinde olmalarının daha önce eğitim aldıkları davranışçı yaklaşımdan kaynaklandığı bildirilmiştir.

Araştırma sonucunda öğretmenlerin görüşleri arasında cinsiyetlerine göre anlamlı bir fark bulunmamıştır. Hizmet yılı olarak 1-5 yıl, 11-15 yıl ve 21 yıl üstü hizmet yılına sahip öğretmen grupları lehine anlamlı farklılaşma olduğu, belirlenen hizmet grubuna dâhil öğretmenlerin, beden eğitimi ve spor öğretim programının temel ilkelerine diğer gruptaki öğretmenlere nazaran daha olumlu yaklaştıkları görülmüştür. 1-5 y1l hizmete sahip öğretmenlerin göreve başladıkları tarih ile programın uygulanmaya konduğu tarih bir birine yakın olduğu için bu öğretmenlerin, programın eğitim öğretim sürecine ilişkin hazır bulunuşluluk düzeylerinin görüşleri üzerinde etkili olduğu düşünülmektedir. 11-15 yıl ve 21 yıl ve üstü öğretmen görüşlerinin; Öğrencilerin eğitiminde, çevresi ve diğer kişilerle deneyimleri önemlidir, öğrenmeöğretme ortamlarında bireysel, eşli ve grupla 
çalışmalar dengeli bir şekilde sunulur, uygulamalar sırasında öğrencilerin, kendilerini fiziksel ve duygusal olarak güvende hissetmeleri önemlidir, öğretim sürecine tüm öğrencilerin katılımı önemlidir ilkelerinde diğer gruplara göre daha olumlu çıkması bu gruptaki öğretmenlerin mesleki tecrübelerinin etkili olabileceği düşünülmektedir. Eğitim durumu açısından öğretmen görüşleri arasında ki farkl1laşmaya, araştırmaya katılan lisans öğrenimine sahip öğretmenlerin lisansüstü öğrenime sahip öğretmenlere göre sayıca daha fazla olmalarıdir.

Araştırma sonuçları dâhilinde şu önerilerde bulunulabilir; araştırma, örneklem grubu daha kapsamlı hale getirilerek tekrarlanabilir. Araştırma, öğretim programının ortaokulun tüm sınıf düzeyinde uygulamasını görüp liseye geçecek öğrencilerle beraber öğretmenlerin görüşleri alınarak bu araştırma sonucu ile karşılaştırılabilir. Araştırma özel okulları da kapsayacak şekilde araştırma grubuna okul yöneticileri ve maarif müfettişleri de dâhil edilerek tekrarlanabilir. Beden eğitimi öğretmenlerine öğretim programının tanıtıldığı mesleki eğitim, kurs ve seminerlerde araştırma sonuçları verilebilir. Okullarda sportif tesislerin yetersizliğine ilişkin ilgili makamlara sunulacak raporlarda araştırma sonuçları kullanılabilir.

\section{Kaynakça}

Alkurt, Z. (2012). Sportif eğitimlerin fiziksel ve sportif gelişime etkisi. Savunma Bilimleri Dergisi, 11 (2), 149-158.

Arslan, Y. ve Altay, F.(2008), Sınıf öğretmenlerinin beden eğitimi ders programı ve ders uygulamalarına ilişkin görüşleri. Hacettepe Spor Bilimleri Dergisi, 19 (2), 63-79.

Avrupa Komisyonu /EACEA/Eurydice (2013). Avrupa'daki Okullarda Beden Eğitimi ve Spor. Eurydice Raporu. <http://eacea.ec.europa.eu/education/eurydice> (2013, Ekim 10).

Avşar, Z. (2009). İlköğretim Öğrencilerinin Beden Eğitimi Dersi Değerlendirme Süreci İle İlgili Görüşlerinin Belirlenmesi. Spor Bilimleri Dergisi, 20 (3), 81-89.

Bilir, P. (2008). Yeni beden eğitimi öğretim programı ve köy enstitülerinde beden eğitimi derslerinin yapılandırmacı öğretim yaklaşımı açısından değerlendirilmesi. Spormetre Beden Eğitimi ve Spor Bilimleri Dergisi, 6, (3), 145-150.

Dalkıran, O., Altıntaş, A., Sunay, H. ve Akgül, M. (2004). Ankara ili devlet ilk ve orta öğretim okullarındaki beden eğitimi öğretmenlerinin ders dişi etkinliklerinde kapali spor alanlarının etkin kullanımı üzerine görüşleri. Spormetre Beden Eğitimi ve Spor Bilimleri Dergisi, 2 (3), 109-118 .

Darst, P.W., Pangrazi, R.P., Sariscsany, M. \& Brusseau, T. (2012). Dynamic Physical Education for Secondary School Students (7th ed.). Benjamin Cummings, Pearson Education Limited, San Francisco.

Demirhan, G., Bulca, Y., Altay, F., Şahin, R., Güvenç, A., Aslan, A., Güven, B., Kangalgil, M., Hüyük, D., Koca, C. ve Açıkçada, C. (2008). Beden eğitimi öğretim programları ve programların yürütülmesine ilişkin paydaş görüşlerinin karşılaştırılması. Spor Bilimleri Dergisi, 2008, 19 (3), 157-180.

Doğar, Y. (1994). Türk Spor Yönetiminde Merkezileşme Eğilimleri. Yayımlanmamış Doktora Tezi. Marmara Üniversitesi, İstanbul.

DPT. (2000). Sekizinci Beş Yıllık Kalkınma Planı Beden Ĕ̆itimi Spor ve İstanbul Olimpiyatları Özel İhtisas Komisyonu Raporu. DPT Yayınları: Ankara.

Erden, M. (1993). Eğitimde Program Değerlendirme. Ankara: Pegem Yayınları.

Fidan, N. ve Erden, M. (2000). Eğitime Giriş. Ankara: Alkım Yayınevi. 
Gülüm, V. ve Bilir, P. (2011). Beden eğitimi öğretim programının uygulanabilme koşulları ile ilgili beden eğitimi öğretmenlerinin görüşleri. Spormetre Beden Ĕ̆itimi ve Spor Bilimleri Dergisi, 9 (2), 57-64.

Güllü, M., Güllü, E. ve Güllü, A. (2009). İlköğretimde çalışan beden eğitimi öğretmenlerinin yapılandırmacı yaklaşıma ve beden eğitimi dersi yeni öğretim programına ilişkin görüşlerinin incelenmesi. Sosyal Bilimler Enstitüsü Dergisi, 3, 217-219.

Güllü, M., Güçlü, M. ve Kafkas. E. (2007). Beden eğitimi öğretmenlerinin 4., 5. ve 6. sinıf beden eğitimi dersi yeni öğretim programı uygulamalarının incelenmesi. IV. Uluslararası Akdeniz Spor Bilimleri Kongresi. 09-11 Kasım, Akdeniz Üniversitesi, Antalya.

Havadar, T. ve Taşdan, M. (2015). Beden eğitimi öğretmenlerinin ilköğretim 4.-5. sınıf öğretim programları hakkında görüşleri (Ardahan, Iğdır ve Kars ili örneği). İnönü Üniversitesi Beden Ĕ̆itimi ve Spor Bilimleri Dergisi, 2 (1), 29-43.

İkizler, H.C. (2000). Sporda Sosyal Bilimler. İstanbul: Alfa Yayınları.

İlköğretim ve Eğitim Kanunu İle Bazı Kanunlarda Değişiklik Yapılmasına Dair Kanun. (11 Nisan 2012.). T.C. Resmî Gazete, 28261.

İnal, A.N. (2013). Beden Eğitimi ve Spor Bilimi. Ankara: Nobel Yayınları.

MEB, (2012). Okul Bahçeleri Düzenleme İlkeleri, İhtiyaç Programları Açıklamaları ve Örnek Projeler. (Ek1). [E:10.06.2015, www.meb.gov.tr/haberler/2012/okullarhayatolsun/protokolEki.pdf]

MEB, Talim ve Terbiye Kurulu Başkanlığı (2013). Beden Eğitimi ve Spor Dersi Öğretim Programı (Ortaokul 5-8. Sinıflar). Ankara.

Milli Eğitim Temel Kanunu. (24 Haziran 1973). T.C. Resmî Gazete, 14574.

Okul Spor Faaliyetleri Yönetmeliği. (5 Kasım 2013). T.C. Resmî Gazete, 28812.

Taşmektepligil, Y., Yılmaz, Ç., İmamoğlu, O. ve Kılcıgil, E. (2006). İlköğretim okullarında beden eğitimi ders hedeflerinin gerçekleşme düzeyi. Spormetre Beden Ĕ̆itimi ve Spor Bilimleri Dergisi, 4 (4), 139147.

Varış, F. (1996). Eğitimde Program Geliştirme "Teori ve Teknikler". Ankara: Alkım Yayınevi.

Yamaner, F. (2001). Beden Eğitimi ve Sporda Temel Illkeler. Bursa: Ekin Kitabevi.

Yıldırım, A., İnce, M.L., Kirazcı, S. ve Çiçek, Ş. (2007). Bedeni eğitimi öğretmenleri ve öğretmen adaylarının derslerindeki akademik öğrenme sürelerinin analizi. Spor Bilimleri Dergisi, 18 (1), 31-41.

Yücel, M. (2004). Gelişim ve öğrenmenin spor kültürünün oluşmasına etkisi. Elazı̆̆g Fırat Üniversitesi Doğu Anadolu Bölgeleri Araştırması Dergisi, 2 (3), 100-108. 


\section{Extended Summary}

The aim of this study is to determine the opinion of physical education class teachers on the basic principles of academic programs of the physical education and sport lessons of 5-6-7-8th classes. This research is important because secondary school (5-6-7-8th classes) academic programs of the physical education and sport lessons which was enacted at 2013-2014 academic year is applied for the first time after separation from primary schools, because it is the first time the opinion of teachers are received on the basic principles of the new program and because it is the first research on the basic principles of the program started two years ago. In the research, answers to following question were sought; what are the physical education teachers' opinions on the basic principles on the secondary school curriculum and is there a differentiation among these opinions by sex, years of service and educational status.

This research is a descriptive study because in this study it was tried to get the opinion of physical education teachers currently working at secondary school and imam-preachers secondary school on the basic principles of academic curriculum of secondary school (5-6-7-8th classes). The research team is formed of 119 physical education teachers ( 34 female and 85 male) who are working at official secondary schools in the city of Sakarya and its central towns in 2014-2015 academic year. Basic principles present at the "MEB Secondary School (5-6-7-8th classes) Physical Education and Sport Lesson Education Curriculum" were converted to a data collection form, a survey was prepared and applied by the researcher. The survey consisted of two sections; In the first section 3 questions related to the demographic characteristics of the participants, in the second section 19 questions related to basic principles of secondary school physical education and sport lesson were present. Responses to questions were five level Likert-type: "1- strongly disagree, 2-disagree, 3- neither agree or disagree 4-agree, 5- strongly agree". In this study, Cronbach's alpha coefficient was used for calculating the reliability of the questionnaire; internal reliability coefficient was found to be 0.84 . Survey was answered by 87 teaches ( 63 male, 24 female).

In the analysis of data, IBM SPSS 22.0 statistics software package was applied and frequency, percentage and arithmetic average was given in descriptive statistics section to determine the opinions of teachers with the demographic data. Kolmogorov-Smirnov test was performed to see the data normally distributed or not and then among nonparametric tests, Kruskal Wallis-H and Mann-Whitney U tests were used for some data which were not normally distributed at the comparison of teachers' opinions according to some demographic variables.

As a result of research, it is observed that general opinions of Physical Education Teachers are positive about the basic principles of the program as a result of two years of implementation of the curriculum of Physical education and sport lesson which has been started to be applied in the academic year of 20132014. When the average of 19 principles, set out for the physical education and sports classes at secondary school, is considered, it is concluded that $48,15 \%$ of teachers agree and $28,85 \%$ of them totally agree with these principles, the total turnout is $77,0 \%$ and the rate of teachers reporting negative opinion is $17,79 \%$. It can be concluded that the basic principles set are able to guide the curriculum as the schools have been restructured and $5^{\text {th }}$ grades included in primary school stage in old system have been included in secondary school stage, at the same time teachers' opinions are positive despite a number of innovations. 
Despite, the overall positive opinion of all principles on the basis of an average, it is noteworthy that about half of the teachers $(48.3 \%)$ don't agree that in the training programs offer fun learning environment. It can be said that the change in the physical conditions as the result of the separation of school buildings, sports facilities, vehicles and lack of healthy planning which is one of the general weaknesses of the education institutions led to this conviction. Dealing with this situation, Ministry of Education stated, in 2012 the school gardens organizing principles, that the need for program descriptions and examples of projects in the school yard, enough ceremony area, sidewalks, green space must be left, surrounded by wire mesh outdoor sports facilities (volleyball, basketball, mini football area) with traditional children's play areas should be allocated to the appropriate place. (MEB, 2012:2). Regulation of School Sports Activities; For the use of fields and facilities in26th article it is stated that "The facilities which belong to Ministry of National Education with General Directorate will take the needed measures by the provincial education directorates with provincial directorates to be used efficiently, competitions and organization provided not be challenged in any hitches" provisions of the place given facility deficient schools arrangement is made. Curriculum process is mainly a helical structure in the developmental principle and It has been observed that about 30\%of the teachers don't agree it. Since the program has started in the 2013-2014 academic year, it can be referred that the results of four years of implementation of the fifth grade students hasn't been seen yet.

According to the research results there is not a meaningful difference in teachers' opinions in terms of their gender. There is a possitive meaningful difference in 1-5 year, 11-15 year, and 21 year \& more experienced teachers, the teachers in these groups were seen to be closer to the main principles of P.E and sport teaching programmes compared to the teacher in the other groups. As the application of the programme and the date of starting the job is very close for $1-5$ year experienced teachers the more possitive attitude of teachers compared to other groups can be atributed to the presence and availability of the programme for the educational process. The more favourable approach of the 11-21 year experienced teachers can be connected to their Professional experience in terms of some principles. The higher quantity of the university graduate teachers compared to the Post graduate teachers can explain for the meaningful difference between these groups.

According to the research results, these suggestions can be made; the research can be redone by expanding the sample group. Research has analysed the application of the programme in secondary school. The opinions of the teachers and the students passing to high school may be taken and compared. The research can again be conducted including the private schools adding school principles and inspectors to the sample group. The research results may be given in educational courses and seminars for P.E teachers in which teaching programmes are introduced. The research findings can help in reports presented to the authorities, about the insufficiency of the sport facilities in schools. 